\title{
The Double Love Commandment
}

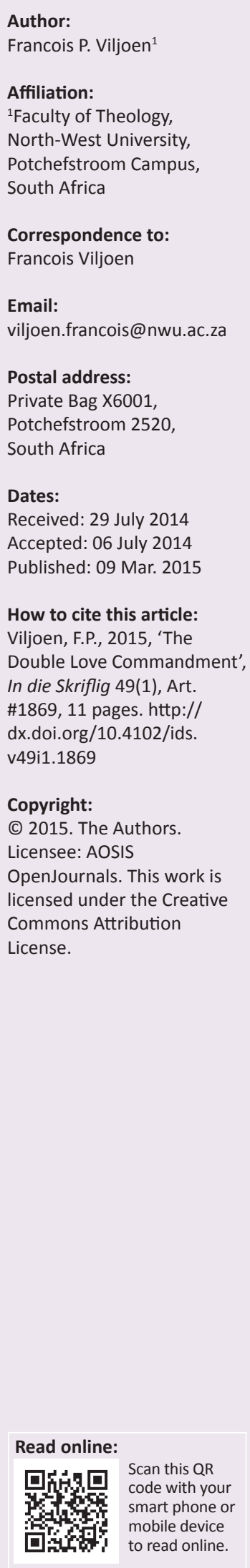

The Gospel of Matthew was written during a period of dispute between the Matthean community and their fellow Jews, with the Pharisees playing a leading role. The Matthean community was heir to the same scriptures as its opponents. They continued to have a firm commitment to the Torah, but they developed a distinctive understanding of it based on Jesus' teaching. The formation of this community is investigated in this article, considering the Mediterranean perspectives of group-oriented societies prevalent in the first century. Such a group provided a sense of self and an interactive support system, where love functioned to bind the group together. The subordinates showed their undivided loyalty towards their superiors because of the favours they received from them, whilst they supported and cared for other members within the group as they care for themselves. Reading the double love commandment of Matthew 22:34-40 from this perspective reveals significant aspects of the community's identity with regard to their commitment to God and their view of their neighbours.

Die Dubbele Liefdesgebod. Die Matteusevangelie is gedurende 'n periode van konflik tussen die Matteusgemeenskap en mede-Jode geskryf met die Fariseërs in 'n leidende rol. Die Matteusgemeenskap het van dieselfde geskrifte as hulle opponente gebruik gemaak. Hulle was steeds aan die Torah lojaal, maar het 'n unieke interpretasie daarvan gehuldig, gebaseer op die onderrig van Jesus. In hierdie artikel word die vorming van die Matteusgemeenskap ondersoek met inagneming van die Mediterreense beskouing van groepgeoriënteerde gemeenskappe wat tipies van die eerste eeu was. So 'n groep het aan individue ' $n$ bewustheid van eie waarde verskaf te midde van 'n interaktiewe ondersteuningsisteem waarin liefde as samebindende faktor gefunksioneer het. Ondergeskiktes het onverdeelde lojaliteit teenoor hulle meerderes betoon vanweë die gunste wat hulle van die meerderes geniet het, terwyl hulle mekaar onderling ondersteun en versorg het, soos wat hulle na hulleself sou omsien. Deur die dubbele liefdesgebod van Matteus 22:34-40 vanuit hierdie perspektief te lees, kom betekenisvolle aspekte van die gemeenskap se identiteit na vore ten opsigte van hulle toewyding aan God en hulle beskouing van hulle naaste.

\section{Introduction}

Matthew 22:34-401 describes yet another scene where the Jewish leaders confront Jesus about the Torah. ${ }^{2}$ This scene concludes a series of hostile interrogations (Streitgesprächen): firstly on whether one should pay tax to the Caesar (22:15-22); secondly on who the husband would be after the resurrection of a woman who had seven husbands on earth (v. 23-33); and thirdly on which commandment of the Torah should be regarded as the greatest. The questions of these challenges are posed in such a manner that whatever Jesus answers, his answer would be embarrassing and damaging to his credibility. However, Jesus time and again overcomes these challenges with his unexpected answers. This series of challenges ends with Jesus taking the lead by posing a question to the Pharisees about the Christ, whose son he is (22:42). After their expected response Jesus poses two more questions (22:43-45). The narrative concludes with the comment that Jesus' opponents were unable to respond and they no longer dared to interrogate Jesus (22:46; Meier 2009:482, 486). ${ }^{3}$ In the following chapter (Mt 23) Jesus warns his disciples and the crowds against the hypocrisy of the scribes and the Pharisees. Jesus is depicted as the undisputed victor in these conflict settings.

\footnotetext{
1.Further references to Matthew will be indicated only by chapters and verses.

2.In 12:2 the Pharisees blames Jesus for the fact that his disciples do what is forbidden on the Sabbath and in 15:2 the Pharisees and the scribes confront Jesus as his disciples do not observe the tradition of hand washing.

3.Jesus possesses all authority ( $\pi \tilde{\sigma} \sigma \alpha \dot{\varepsilon} \xi o u \sigma i \alpha$ ), and Matthew once again presents Jesus as the victor in this case (cf. 7:29; 23:23-27; 28:18).
} 
This article forms part of a series of articles on Torah related issues in the first Gospel. The role of the Torah, both the written version and the Jewish scribal teaching based on it, forms a prominent theme in Matthew in its relation to Jesus and his teaching. The author of this Gospel, with his distinctive aims and in his own editorial manner, tells what Jesus taught about the Torah (e.g. the Sermon on the Mount in Mt 5-7), how he acted in Torah related circumstances (e.g. eating with tax collectors and sinners in 9:10-13, touching impure persons in 8:3 and 9:20 and a dead girl in 9:25), and how he responded to questions about the Torah (e.g. the Sabbath in 12:1-4 and the traditions of the Pharisees in 15:1-20). Jesus' response to the question about the greatest commandment (22:34-40) forms an important component of the discussion of the Torah in Matthew.

In this article, the conflict story about the greatest commandment is read on two levels. The first level relates the conflict between an expert of the Law and Jesus, and functions within the story world internal to the text. The conflict between the Jewish religious leaders and Jesus with his followers forms a central theme throughout Matthew's Gospel (see Stanton 1992:113-145). In Matthew this hostility is described much sharper and more continuously than in the other Gospels. Whenever Matthew writes about the religious leaders as opponents of Jesus, the Pharisees ${ }^{4}$ emerge prominently as the main opponents (Repschinski 2000:325). The second level reflects the external world in which the text came into existence. It is plausible to assume that the controversy between the Pharisees and Jesus in the Gospel reflects at least some of the tension between the Matthean community and the Pharisees, and the heirs they had contact with in their days and society (Repschinski 2000:326). The Gospel was written during a period of dispute with fellow Jews where some Pharisaic sects played a leading role. Matthew's community felt seriously threatened by these Jews (Stanton 2013:112-115). The Matthean community was heir to the same scriptures as its opponents and continued to have a firm commitment to the Torah, but they developed a distinctive understanding of it, based on the teaching of Jesus. In terms of specific Torah observance, they developed different forms of piety and ethics. Eventually this led to a

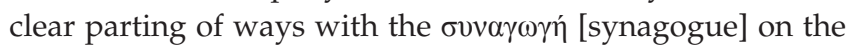
one hand and the sand the [church] on the other. ${ }^{5}$

The formation of this community is investigated, considering the Mediterranean perspectives of group-oriented societies that were prevalent in the first century. In such societies, meaningful human existence relied on being embedded in a group (Malina \& Rohrbaugh 1992:57). Such a group provided a sense of self and an interactive support system where love

4.The role of the Pharisees in Matthew and the other Gospel has prompted much investigation. Serious doubts have been raised as to whether the historical Pharisees indeed were the main opponents of the historical Jesus. Berger (1972:576-578) indeed were the main opponents of the historical Jesus. Berger (1972:576-578) argues that the stories about the antagonism between the Pharisees and Jesus only developed in the early Christian traditions. It is representative of the controversie between the early Christian communities and some Pharisaic sects of their days (cf. 1985:287-293

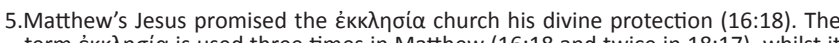

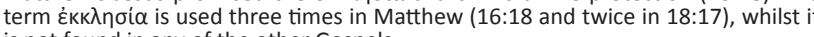
is not found in any of the other Gospels. functioned to bind the group together. The subordinates showed their undivided loyalty towards their superiors because of the favours they received from them, whilst they supported and cared for other members of the group as themselves. Reading the double love commandment of 22:34-40 from this perspective reveals significant aspects of the community's identity, which will be explored in this article.

\section{Composition of the narrative}

The composition of this short narrative is straight forward (Box 1). It consists of a narrative introduction that describes the setting of the challenge (22:34-35), the short challenging question of the expert of the Law (22:36), and the longer answer of Jesus as riposte. This riposte consists of two components (22:37-40) in which Jesus overcomes the challenge by quoting and linking two passages from the Torah: the first about the vertical dimension of love (quoting from Dt 6:5), and the second on the horizontal dimension (quoting from Lv 19:18). The narrative concludes with a comment about the significance of the commandments as quoted.

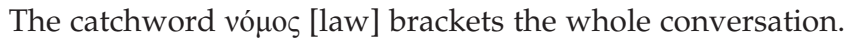
The Law is the contents and real focus of the discussion. The

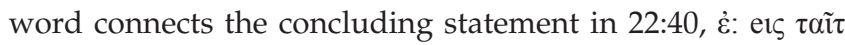

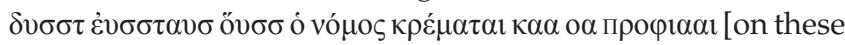
two commandments hang all the Law and the Prophets], with the person who asks the question in the opening verse,

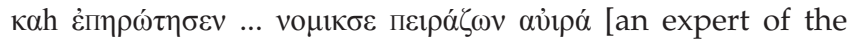
Law, tested him asking] (22:35; Luz 2001:75).

Matthew follows Mark's version (Mk 12:28-34) of the event, but with significant differences (see Hultgren 1974:374), which demonstrates some of the intentions and concerns of Matthew. The two passages are presented in parallel form to indicate omissions and additions by Matthew on Mark's version (Table 1). Significant changes are indicated in bold.

Matthew omits a number of sections from Mark's text. The first omission is 'noticing that Jesus had given them a good answer' (Mk 12:28). The reason for this omission is most probably that such an amicable remark would not form a fitting setting for a challenge by this very same person, Jesus. The second, somewhat surprising omission is the quotation of the Shema: 'Hear, o Israel, the Lord our God,

\section{BOX 1: Composition of the narrative.}

\begin{tabular}{|c|}
\hline 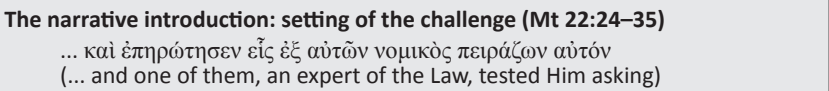 \\
\hline The question to test Jesus: challenge (Mt 22:36) \\
\hline 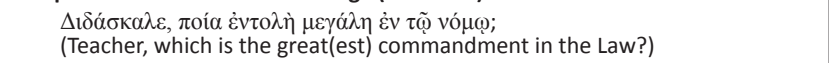 \\
\hline Jesus' twofold response: riposte (Mt 22:37-40) \\
\hline 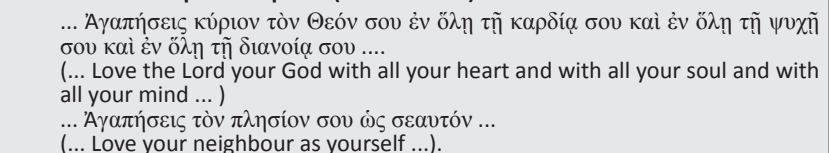 \\
\hline
\end{tabular}




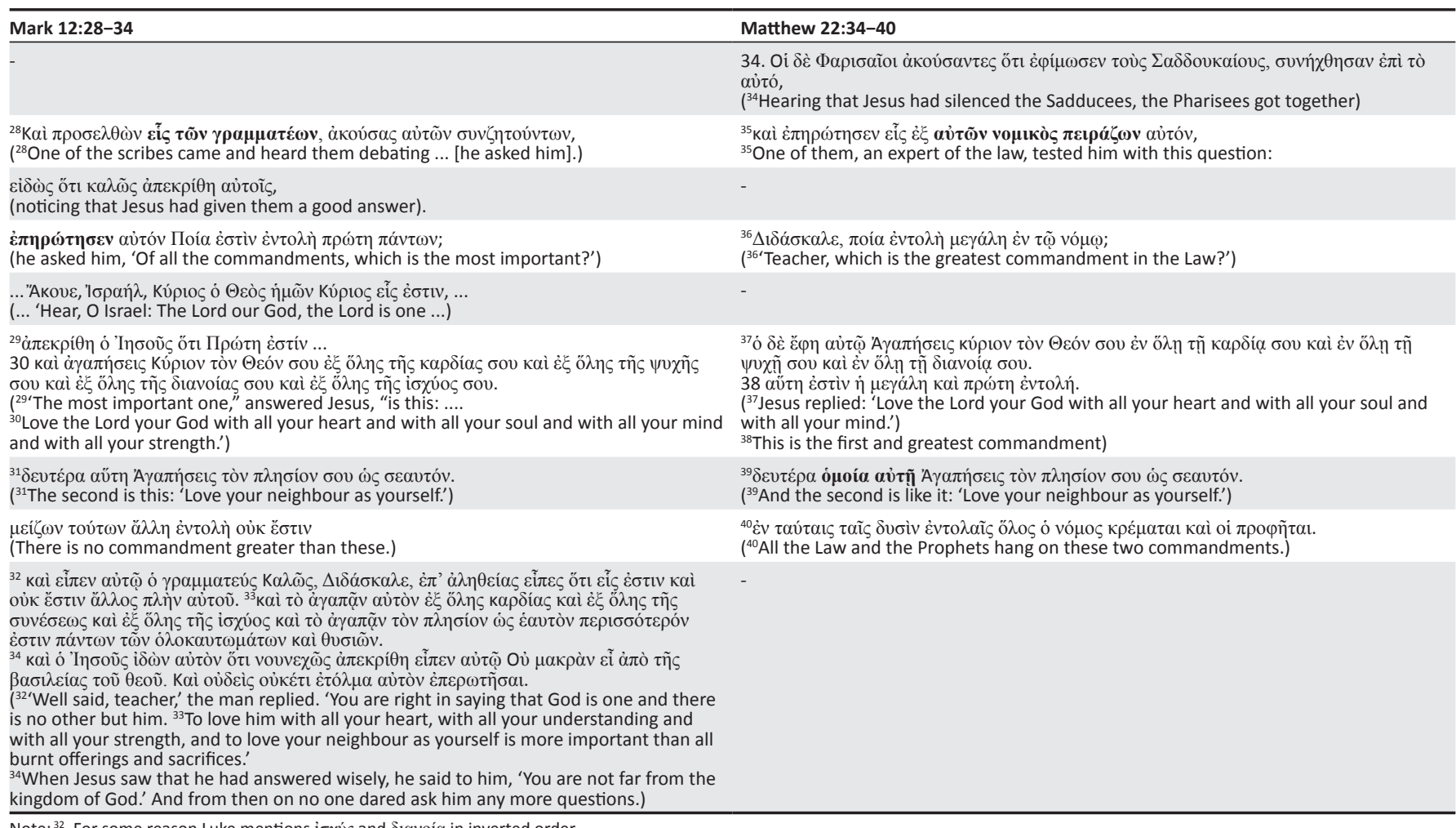

the Lord is one' (Mk 12:29). It is a redactional tendency of Matthew to shorten Mark so that he can focus on the essence of his argument. The Shema seemingly does not form an essential part of Matthew's argument and he probably assumes that his mainly Jewish readers would associate the first commandment, as quoted, with the Shema. ${ }^{6}$ Matthew also omits one of the four faculties Mark mentions, that is, 'with all your strength' (Mk 12:33), reducing the number of qualifications to three faculties as in Deuteronomium 6:5. However, the phrase 'with all your strength' Matthew leaves out, is found in Deuteronomium 6:5, whilst he maintains 'with all your mind', which is an addition to Deuteronomium 6:5. This probably reflects a certain understanding of the character of love. The longest omission is where the scribe admits that Jesus is right, and Jesus commends him by stating that he is not far from the kingdom of God (Mk 12:32-34). Such an amicable remark obviously would not fit well into the Streitgespräch and the increasing hostility that Matthew describes in his narrative (Hagner 1995:645; Loader 1997:235). Matthew rather continues with a conflict setting where the opposition deepens to reach its climax in the denunciation of the Pharisees in Matthew 23.

On the other hand, Matthew makes a number of additions to the text. The entirety of 22:34 is added, which indicates that this is yet another attempt of the Pharisees to tempt Jesus. Matthew replaces 'one of the scribes' (Mk 12:28) with 'and expert of the Law' (22:35) to indicate how formidable

6.Though omitting the opening confession of faith of the Shema, Matthew's Jesus responds with the love of Yahweh, taken from Deuteronomium 6:4-5. In later rabbinic period, the Shema had become to be defined as containing three rabbinic period, the Shema had become to be defined as containing three
texts joined together: Deuteronomium 6:4-9; $11: 13-21$ and Numeri 15:37-41 texts joined togethe
(Meier 2009:490). this challenger as spokesperson of the Pharisees is. Matthew replaces the positive attitude of the scribe who asks Jesus a question (Mk 12:28) with a challenge of testing Jesus (22:35). Furthermore, Matthew adds 'teacher' as the addressee (22:36), a term that only Jesus' adversaries use to address him in Matthew and never his adherents. In 22:38 a remark about the first commandment is added: 'this is the first and greatest commandment', and to the second commandment 'similar to it' $^{\prime}$ (22:39) is added. Furthermore, Matthew replaces Mark's 'there is no commandment greater than these' (Mk 12:31) with 'all the Law and the Prophets hang on these two commandments' (22:40), which indicates the significance of these two commandments for the interpretation of all the Jewish scriptures.

The general tendency of Matthew to shorten Mark's narrative is once again evident in this story. What is more, Matthew amends Mark's version to create a better parallel between the two commandments as the first and second commandments respectively. With this shortened story in which he presents the issue of the Law in parallel form, Matthew succeeds in creating a sharp focus on the Law.

\section{Reading the story as Streitgespräch}

Back in 1954, Bornkamm (1954:85-93) expounded how Matthew turns the didactic story (Schulgespräch) of Mark ${ }^{7}$ on the greatest commandment (which has an amiable tone) into

7.Though Mark 12:28-34 is usually described as a Schulgespräch, an irenic dialogue does not really fit into the series of preceding conflict stories and Jesus' attack on the scribes that follows. Meier (2009:499) is of the opinion that Mark 12:28-34 probably circulated originally as an independent oral tradition. 
a conflict story (Streitgespräch) ${ }^{8}$ (which has a controversial tone). Matthew's story forms a continuation of two previous conflict stories, namely the stories on the payment of taxes (22:15-22) and about the resurrection (22:23-33) (Repschinski 2000:262). Despite their agreement with Jesus in the dispute on the resurrection, the Pharisees in the story side with the Sadducees in a continuing conflict setting. One would expect the Pharisees to rejoice in the Sadducees' defeat, as they were usually were rivalling Jewish factions, but in this instance they conspire together against Jesus as is also the case in 16:1-2. The Pharisees are determined to challenge Jesus and use the expert of the Law as their spokesperson. Matthew concludes the story on the greatest commandment by depicting Jesus as the victor. The expert of the Law and the Pharisees are silenced. Jesus then continues by asking a question of his own: 'What do you think of the Messiah?' (22:42). Matthew's Jesus continues with a Christological revelation about David calling his son 'Lord' (22:41-46). Matthew creates tension with a climactic ending by delaying the last statement of Mark 12:34, 'no one dared ask him any more questions' to end this passage. In this Streitgespräch Jesus is the clear victor.

A central phenomenon to a Streitgespräch is the interaction of challenge and riposte (Malina \& Rohrbaugh 1992:42; Repshinski 2000:262-272). It consists of a challenge with the intention to undermine another person's reputation and a response that measures up to the challenge. Honour and shame were pivotal values in ancient Mediterranean societies (Malina \& Rohrbaugh 1992:76). Honour is acquired by the conduct of a person, but also by the recognition of it by others. In this Streitgespräch the intention of the expert of the Law and the Pharisees is to shame Jesus. However, Jesus acquires honour by his skilful riposte to this challenge. The Pharisees witness Jesus' victory in this Streitgespräch. Instead of recognising Jesus' honour, their jealousy apparently increases. In Matthew 23 Jesus continues by addressing the crowds and his disciples by warning them against the scribes and the Pharisees. They witness how Jesus maintains his honour, whilst he exposes the shame of the Jewish leaders. Jesus emerges as the clear victor and the respect the disciples and crowds have for him, increases.

By presenting this event in the form of a Streitgespräch Matthew expresses his and his community's opposition to the Rabbinate of their society regarding the understanding of the Law (Barth 1963:76). The evangelist pronounces the conflicting hermeneutical approaches to the Law and prophets by the Pharisees of their day, and of his own community (Hultgren 1974:378).

\section{The polemical challenge by the expert of the law (22:24-36)}

This scene opens with a remark that refers back to the previous Streitgespräch where Jesus put the Sadducees to silence. Their inability to respond is implied, غ̇mpliedi $\tau$ ool

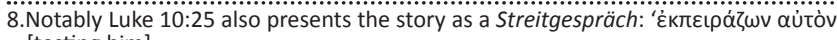
[testing him].
$\Sigma \alpha \delta \delta$ ovкaíous [He silenced the Sadducees]. It is not merely that the Sadducees did not say anything, but they could not say anything. Jesus was the clear victor in the previous dispute. The dispute then continues with the challenge from the teacher of the Law.

Whilst Mark only mentions one scribe questioning Jesus (Mk 12:28), ${ }^{9}$ Matthew adds the presence of the Pharisees in this hostile debate. Matthew writes that the 'Pharisees were gathered together' ( $\sigma v v \eta \dot{\eta} \chi \emptyset \eta \sigma \alpha v)$, which could be an intended echo of Psalm 2:210 (Carter 2000:444; Osborne 2010:822; Turner 2008:535). The scene suggests a full scale assembly for a concerted and malicious effort by the Pharisees. ${ }^{11}$ They use the expert of the Law as their spokesperson in this Streitgespräch.

Whilst Mark uses $\gamma \rho \alpha \mu \mu \alpha \tau \varepsilon \dot{\varsigma}$ (Mk 12:28) and Matthew usually also uses $\gamma \rho \alpha \mu \mu \alpha \tau \varepsilon$ s to refer to a scribe (e.g. 2:4; 5:20; 7:29), Matthew here uses the word vouıкor [expert of the Law]. As a matter of fact this is the only time Matthew uses this word vоника. Obviously Matthew wants to emphasise that the questioner should be regarded as a daunting interlocutor about this crucial legal issue (regarding the vouós) at stake (Gerhardsson 1976:133; Osborne 2010:822). The terms used to describe the conduct of the expert of the Law, underlines the

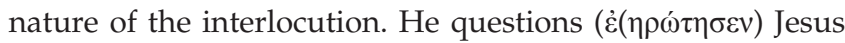
(using the intensified form of żusing, [ask]) whilst trying to

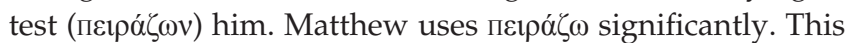
word is also used in other malicious debates and temptations in Matthew $(16: 1 ; 19: 3 ; 21: 45 ; 22: 15-18)$ where the Pharisees are also involved. Furthermore, the supreme tempter, the devil, is called ois [the tempter] (4:1). Clearly the intention of the vонике [expert of the Law] is not to ascertain the truth, but to shame Jesus by tricking him to give a disputable answer on legal matters.

The expert of the Law addresses Jesus as teacher $(\delta 1 \delta \alpha \sigma \kappa \alpha \lambda \circ \zeta)$. At first this form of address does not indicate hostility. In Matthew, only Jesus' adversaries address him as teacher, namely the scribes, Pharisees, collectors of temple tax and the rich young man who goes away disappointed with Jesus' answer. ${ }^{12}$ People who respect and

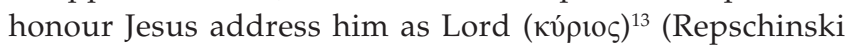

9. As indicated above, Matthew omits the positive and amicable attitude of the teacher of the Law reflected in Mark 12:28: 'Noticing that Jesus had given them a good answer' and adds that he tried to test Jesus.

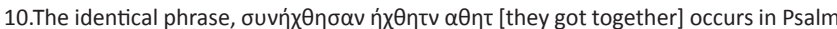
2:2 LXX. Within the context of opposition against the Lord's anointed, Psalm 2:2 reads: 'The kings of the earth rise up and the rulers band together against the Lord and against his anointed'. Reference to Psalm 2:2 is also made in Acts 4:26. Lord and against his anointed'. Reference to Psalm 2:2
Nehemia 6:2 describes a similar malicious gathering.

11.In Matthew Jewish religious leaders, in particular the scribes and the Pharisees, are consistently described in a negative light. Whilst Mark only once refers to Pharisees as hypocrites (Mk 7:6) and Luke not at all, Matthew makes 12 such references, of which 6 are in Matthew 23 (see Stanton 2013:108-112).

12.Jesus is addressed as teacher ( $\delta เ \delta \alpha \dot{\sigma} \sigma \alpha \lambda \circ \varsigma)$ by a scribe who tells Jesus that he would follow him, but he receives a disappointing answer from Jesus (8:18); by scribes and Pharisees asking a sign from Jesus (12:38); by the rich young man who asks what good deed he must do to get eternal life (19:16), by the Pharisees who challenge Jesus on the payment of taxes (22:16) and the Sadducees who challenge him on the resurrection (22:24).

13.Jesus is addressed as Lord (кúpıoৎ) by his disciples when they call for help during the storm at sea (8:25); by the two blind men who Jesus heals $(9: 28)$, by Peter when he loses faith while walking on the sea (14:30), et cetera. 
2000:274). It seems that the expert of the Law uses 'teacher' in an ironic or even sarcastic way. If Jesus pretends to be a teacher (rabbi) who has adherents, let he then prove himself really to be a teacher. By addressing Jesus as teacher, the expert of the Law expresses his sinister intention to challenge Jesus' honour. His intention is clearly not to gain new insight into the Law, but to challenge Jesus to give a disputable or wrong answer. Thus, he would get an opportunity to shame and ridicule Jesus. With this challenge he wants to demonstrate Jesus' ignorance and unworthiness of being regarded as a credible rabbi. The teacher of the Law asks Jesus about the great(est) command ( $\dot{\varepsilon}$ comm $\mu \varepsilon \gamma \alpha \dot{\lambda} \lambda \eta)^{14}$ of the Law. He wants Jesus to single out one commandment that stands qualitatively above the rest. This was a typical point of debate amongst the rabbi's (Hagner 1995:646; Keener 2009:530; Luz 2001:82). They counted 248 commandments and 365 prohibitions. To underline the seriousness of the Law, they often warned that the violation of even the smallest commandment of the Law is extremely serious as some have remarked: 'Violating even a light commandment is the result of pride' (4 Mc 5:20-21) and commended even the smallest commandments: 'Scriptures credit both light and weighty' (b. Hag. 5a). James poses a similar warning: 'For whoever keeps the whole law and yet stumbles at just one point is guilty of breaking all of it' (Jm 2:10). The question of the expert of the Law is therefore an excellent challenge posed to Jesus. Whichever commandment Jesus singles out, it would be disputable.

Whilst the rabbi's accepted all commandments as given by God so that none could therefore be neglected, they did distinguish between 'heavy' and 'light' commandments ${ }^{15}$ (cf. Hillel's middoth, rules 1 \& 5; Gerhardsson 1976:137). Montefiore and Loewe (1974:199-201) indicate several rabbinic passages ${ }^{16}$ in which commandments are prioritised. The Babylonian Talmud, b. Sanh. 74a for example, refers to martyrdom when Jews are forced into committing sins. The Talmud identifies some specific sins that were absolutely prohibited during such martyrdom, namely idolatry, unchastity and murder. Neighbourly love has long been regarded as fundamental in Jewish ethics ( $m$. Abot. 1:12; Jub 36:4, 8). Late in the first century, Rabbi Akiba regarded neighbourly love as the greatest commandment of the Law (Sifra Qed.pq. 4.200.3.7). Other rabbi's again stressed the prohibition of idolatry ( $b$. Qidd. 40a; p. Ned. 3:9). Similar discussions on which of the laws should be regarded as the 'greatest' are found in $m$. Hag., 1:8; b. Mak., 24a; b. Ber., 63a; b. Sabb., 31a; cf. Hultgren 1974:376; Keener 2009:530).

14. Matthew here probably uses the Semitic style of the superlative, which also became common in Koine Greek (cf. Keener 2009:530; Turner 2008:535).

15. In 23:23 Jesus charges the Pharisees that they regarded some commandments so important that they neglected others: 'You give a tenth of your spices-mint, dill and cumin. But you have neglected the more important matters of the law-justice, mercy and faithfulness. You should have practiced the latter, without neglecting the former.'

16.Though such rabbinic writings are dated later, it can be assumed that they reflect earlier Jewish thinking that was prevalent in the times of Jesus and the Matthean community.
The teacher of the Law is therefore initiating a discussion that would provide an opportunity to trap Jesus into giving a disputable answer and thus damaging Jesus' reputation.

\section{The non-polemical riposte given by Jesus (22:37-40)}

In this Streitgespräch Jesus responds with a twofold answer: the first focusing on one's relationship with God (22:37$38)$, the second on one's relationship with one's neighbour (22:39), and a concluding remark about the centrality of these two commandments (22:40). ${ }^{17}$ There is nothing polemical in Jesus' answer, but according to Matthew, this answer leaves the expert of the Law speechless. Jesus is portrayed as the honourable figure at the scene.

\section{Love of God}

In the first part of his response Jesus focuses on the first table of the Decalogue and describes the vertical dimension between a human and God. ${ }^{18}$ This response is uncontroversial and not polemical, but defuses much of the challenge. Whilst

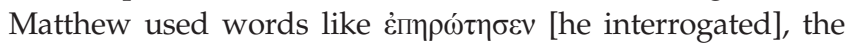

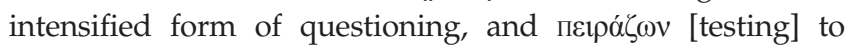
describe the challenge put by the expert of the law, he uses a non-polemical neutral word, čeu [he stated] to describe Jesus' response. Though without the opening words of the Shema as in Mark ${ }_{\prime \prime}{ }^{19}$ Matthew's Jesus cites the part of the Shema dealing

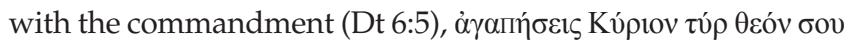

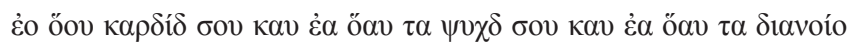
бov [love the Lord your God with all your heart and with all your soul and with all your mind]. The citation of the Shema is significant as it was a central and well-known text in Judaism (Meier 2009:490). Pious Jews recited it twice daily. The Israelites had to memorise these words, instruct their children, write out the Torah, and wear fringes (tzitzit) to remind themselves of these words. Judaism stressed the importance of loving God with one's whole being (Jub 1:15-16; 16:25; 1 QS. 1.2). By stating the importance of this commandment, Jesus asserts that he firmly stands within this tradition, and thus avoids the embarrassment the teacher of the Law might have expected.

Interpreting the meaning of the love of God, one must consider the group orientation of the 1st century Mediterranean world. Love formed part of a positive reciprocity within the group (Malina \& Rohrbaugh 1992:56). Balanced reciprocity implied that one should return in equal measure to the favour one receives. ${ }^{20}$ The love of God

17.From the text itself it is not clear whether this concluding remark is made by Matthews' Jesus or whether it is a direct comment by the author himself.

18.This commandment from Deuteronomium 6:5 can easily be identified with the first commandment of the Decalogue: 'I am the Lord your God ... You shall have no other gods before me' (Ex 20:2-3).

19. Matthew, writing to a mainly Jewish-Christian audience, probably assumes his audience would relate the commandment to the Shema, ('Hear, o Israel, the Lord our God, the Lord is one').

20.The requirement to return favours becomes clearer when considering the context of treaties (covenants) in the Ancient Near East. In some of these treaties, the vassal, often after being defeated in battle, promised to 'love' the suzerain. 'Love' implies the fulfilment of the obligations the suzerain imposes on the vassal in the treaty, above all maintaining the exclusive relationship with the suzerain (Meier 2009:490). 
TABLE 2: Comparison of the faculties.

\begin{tabular}{|c|c|c|c|c|}
\hline MT & LXX & Mark 12:30 & Matthew 22:37 & Luke 10:27 \\
\hline Lēb & 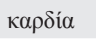 & 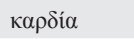 & $\kappa \alpha \rho \delta i ́ \alpha$ & 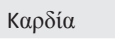 \\
\hline nepeš & $\psi v \chi \eta ́$ & $\psi v \chi \eta ́$ & $\psi v \chi \eta ́$ & $\Psi v \chi \eta ́ ~$ \\
\hline- & - & 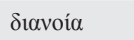 & 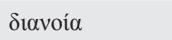 & $\delta 1 \alpha v o i \alpha^{32}$ \\
\hline měōod & $\delta v ́ v \alpha \mu \iota \varsigma$ & iv́vōd & - & iv́vōd \\
\hline
\end{tabular}

functions on the vertical dimension. The people of God considered themselves as receiving their whole existence and well-being from God (from top to bottom). Matthew depicts God as merciful, gracious and loving (9:13; 12:7). Such privileged people should therefore respond with honour, loyalty and devotion (from bottom to top). God formed the ultimate personage of their group. Loving God implied attachment to God and behaviour that would honour him within this reciprocal relationship. Love implies the fulfilment of required obligations within such a relationship (Meier 2009:490).

As in the Shema, Jesus continues to describe the way one should love God with a trisected series of nouns describing a person's faculties. These faculties were regarded as the different constituents of a human being that influence his or her behaviour. The faculties differ in the synoptic versions as indicated in Table 2.

The Shema in the Masoretic Text and the LXX refers to three faculties (with all your heart, and with all your soul and with all your strength) (Dt 6:5). ${ }^{21}$ Mark adds a fourth faculty,

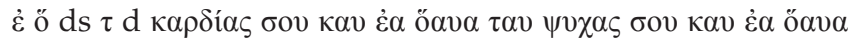

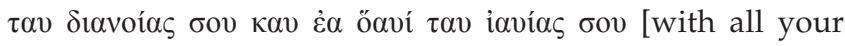
heart and with all your soul and with all your mind and with all your strength] (Mk 12:30). As in the Shema, 22:37

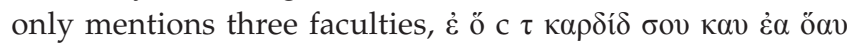

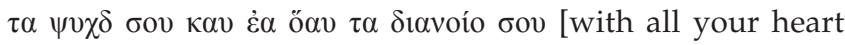
and with all your soul and with all your mind], ${ }^{22}$ though the last one (all your mind) is similar to the fourth faculty in Mark and differs from the third faculty of the Shema, 'all your strength'. ${ }^{23}$ Luke 10:27 followed Mark by mentioning

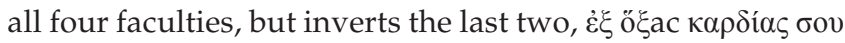

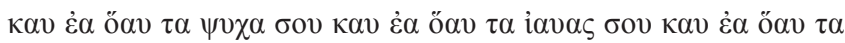

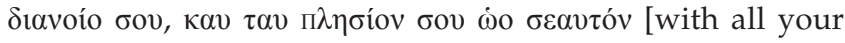
heart and with all your soul and with all your strength and with all your mind].

The faculties, as mentioned, represent the entire person. One cannot love God with some of one's faculties, whilst excluding others. Nevertheless, in Jewish tradition each faculty gathered interpretation to itself as it referred to a functional composite part of a human being (Davies \& Allison 2004:241; Gerhardsson 1976:140).

21.The combination of "heart and soul' signifying loving in entirety is found in Jewish writings (Jub 1:15-16; 16:25; 1 QS 1.2).

22. Matthew is closer to the Masoretic text and LXX by introducing the faculties with $\dot{\varepsilon} v$ plus the dative, instead of $\dot{\varepsilon} \xi$ plus the genitive as in Mark.

23. Interesting enough, Plautus also combined these faculties: 'I'll work my hardest for, and follow up with corde et animo atque viribus (with heart and soul and strengths)' (Captivi 2.3.27).
The first faculty Jesus refers to, 'all your heart', is found in all the versions as indicated in the table above. Heart is mentioned over 800 times in the Bible, but never referring to the literal physical pump that drives the blood. One's heart was regarded as the centre of one's thoughts, will, knowledge, decisions and actions (Jacob 1974:626; Walker 2000:563). It refers to the affective centre or desire producer of one's being. The following two verses from the Jewish Bible illustrate the point. In Jeremiah 32:41 lēb [heart] refers to the place of willing and planning, and in 1 Sameul 12:20 to the source of religious and ethical conduct (Baumgartel 1978:606-607). In the New Testament к $\alpha \rho \delta i \alpha$ [heart] is used with a similar meaning. It refers to one's religious centre, which forms the root of religious life and determines ethical conduct (Lk 16:15; Rm 5:5; 8:27; Eph 3:17), it is the seat of thought and understanding (Mt 7:21; Jn 12:40; Ac 8:22; Behm 1978:611-613). Jesus therefore states that one should be totally devoted to God with one's inmost religious centre (Piper 1979:205).

The second faculty 'all your soul' is also found in all the versions. $\psi v \chi \eta$ [soul] is etymologically related to $\psi v \dot{\chi} \chi \omega$ [blow]. In the Jewish Bible the soul is regarded as the direct result of God breathing (blowing) his gift of life into a person (Gn 2:7).

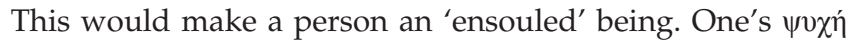
is the vital force, which comes to expression especially in breathing. At the moment of death the $\psi v \chi \eta$ leaves a person (Dihle 1974:609). In Hebrew Bible nepeš [soul] is regarded as the decisive mark of a living creature (Ps 16:10; Jacob 1974:618). In the New Testament $\psi v \chi \eta$ is used with similar meaning. In 2:20 the Herod seeks the $\psi v \chi \eta$ of Jesus. Jesus announces that he would give his $\psi v \chi \eta$ as ransom for many

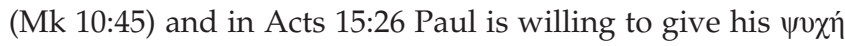
for the sake of the name of the Lord Jesus Christ (Schweizer 1974:637-656). The word soul thus frequently designates the life force of a living creature (Carrigan 2000:1245). Reference to 'all your soul' therefore signifies that one should totally surrender one's life to God. Loving God with all your soul therefore implies that one should be devoted to God and his commandments even to the point of martyrdom.

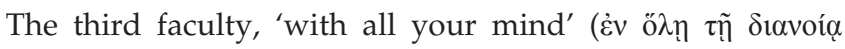
$\sigma o v)$, does not occur in Deuteronomium 6:5, but Matthew probably took it over from Mark's addition of the faculty, whilst he leaves out 'with all your strength' ( $\dot{\varepsilon} \xi$ ö $\lambda \eta \varsigma \tau \tilde{\eta} \varsigma$ i $\sigma \chi v 0 \varsigma$ $\sigma o v)$. One's mind ( $\delta 1 \alpha v o i ́ \alpha)$ was regarded as the seat of one's intellectual capacity, of reason, apprehension and insight (Spencer 2000:901; Würthwein 1978:963). It represents the faculty of thorough reasoning (Mk 12:30; Heb 8:10; 10:16). It incorporates both sides of a matter to reach meaningful and personal conclusions. Colossians 1:21 refers to the preChristian mode of thinking, being alienated and hostile

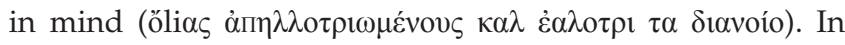
Ephesians 4:17-18 the defect of the vo $t$ [mind] is traced back

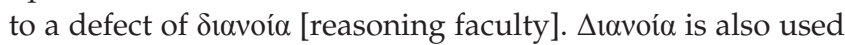
of reasoning and speech between characters in ancient Greek dramas (Aristotle Rhet. 1.404). Matthew's Jesus states that such 'full-breadth reasoning' is essential to loving the Lord 
God. Matthew's omission of 'strength', whilst maintaining 'mind' suggests an intellectual approach to the love of

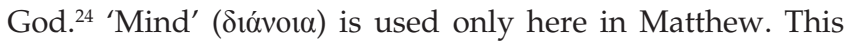
fits in with some Jewish interpretations of the 'love of God' in Deuteronomium 6:5, referring mainly to faithfulness to the Torah (see b. Ber. 61b; Philo Decal. 64). Luz (2001:82) proposes that a Hellenistic Jewish tradition lies behind this choice. According to this tradition loving God does not entail a mere feeling or mystical flight out of this world. Instead, for Hellenistic Jews it implied knowing God and obeying his commandments, carefully considering all reasoning. Once again Matthew's Jesus defuses the challenge of the teacher of the Law. A person, who loves God with his or her entire mind, would also obey all the commandments he has given. One's whole reasoning should be orientated towards God and obeying his commandments (Carter 2000:445). Thus, the love of God becomes the fundamental and first commandment that would incorporate the other commandments.

Jesus therefore concludes this first part of his response by stating that this commandment is the most important,

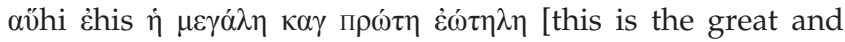
first commandment] (22:38). This statement in Matthew is unparalleled in Mark and Luke, though Josephus also uses $\pi \rho \omega \dot{\tau} \eta$ to refer to the first commandment (Contra Apionem 2.190). ${ }^{25}$ Jesus confirms that this commandment forms the beginning of all obedience and ethics.

\section{Love of neighbours}

Being loyal towards God and his commandments provides a logical link to the second commandment Jesus adds. In the ancient Mediterranean world the identity of the group was dependent on the honour and status of personages (patrons) of the group and members of the group considered themselves embedded into these personages (Malina \& Neyrey 1996:167). Love implied faithfulness and loyalty towards personages in whom one was embedded. This required obedience to prescribed duties towards the one in whom one is embedded. A religious person is embedded into God. Love of God therefore requires loyalty to his will and commandments, which entails loving the other members of the group. The obligation to show love towards one's neighbours is motivated by the love one receives from God (cf. 18:21-35; Barth 1963:85).

Without waiting for a reaction from the expert of the Law,

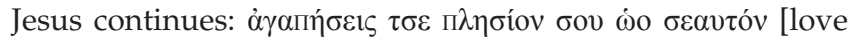
your neighbour as yourself] (22:39). Philo (Decal. 109-110) similarly remarks that the two halves of the Decalogue, the love of God and the love of one's neighbour, are incomplete without one another. This second part focuses on the second

24.Strength (ioxúc) refers to one's energy and power. Mark uses this term to describe the power of God (Mk 9:1; 12:24; 14:62) and of Jesus (Mk 5:30; 6:2, 5, 14; Stein 2008:561).

25.'What are the things then that we are commanded or forbidden? - They are simply and easily known. The first command is concerning God, and affirms that God contains all things, and is a being every way perfect and happy, self-sufficient, and supplying all other beings; the beginning, the middle, and the end of all things ... (Contra Apionem 2.190). table of the Decalogue, the horizontal dimension. ${ }^{26}$ This wording follows that of Leviticus 19:18. It is significant that Matthew's Jesus has cited Leviticus 19:18 twice before (5:42; 19:19; Piper 1979:152). Both of these references are unique to Matthew. Leviticus 19:18 is also the most cited Old Testament text in Matthew's Gospel. In 5:43 Jesus broadens the meaning of one's neighbour to even include loving enemies (Piper 1979:141). In 19:19 Jesus cites Leviticus 19:18 to be the fundamental summary of the moral demands of the Decalogue, namely 'You shall not murder, you shall not commit adultery, you shall not steal, you shall not give false testimony, honour your father and mother'. In 22:39 this commandment is brought into close connection with loving God ócom $\alpha$ av่co [similar to it]. It is clear that this commandment forms an important part in Matthew's ethics. Davies and Allison (2004:241) remark that Matthew thus fuses religion and ethics. This fits well with the connection of religion and group identity in the ancient Mediterranean world (Malina \& Neyrey 1996:167). Performing one's duties towards one's neighbours was regarded as part of one's piety directed at God.

The question arises why Jesus calls this the second ( $\delta \varepsilon v \tau \dot{\varepsilon} \rho \alpha)$ commandment. Does it refer to the second in number or second in importance? In answer to this question one should consider the use of on a $\alpha$ avn, by which the importance of the second commandment is emphasised. In Jewish interpretation the love for God and the love for one's neighbour are closely related, as it is also found elsewhere in Jewish sources. Testament of Benjamin 3.3-4 states: 'fear of God and honouring the brothers ... [are] the essence of the Law' (see also Test. of Issachar 5:2; 7:5; Test. of Dan 5:3). In some cases they are even identified with one another. Epistle of Aristoteles 229 speaks of the pious person who will be helped by the love of the Lord which he has for his neighbour. In 10:40 Jesus also emphasises the close link between the love of God and the love of people stating that a person who welcomes a disciple, actually also welcomes Jesus and God. Jesus confirms this link once again in 25:31-46. Love of God is demonstrated in feeding the poor, housing the homeless, clothing the naked, et cetera (Carter 2000:445). Though this command is second in number, it remains equally important. As a matter of fact, it forms part and is the logical result of executing the first commandment. According to the Jewish interpretive principle of gezerah shewah [equal category], it was common to link two commandments together based on their opening words. In Matthew 22 the opening words, 'you shall love' are the same, but the objects of love differ: love of God and love of neighbours (Keener 2009:531; Meier 2009:493; Turner 2008:536). Matthew presents the double love commandment in a chiastic structure, which gives each of the quoted commandments equal weight (Repschinski 2000:263). In order to create a better parallel between the two commandments he amends Mark's version (Box 2).

26.In Romans 13:8-11 Paul also states that loving one's neighbour is the fulfilment of the Law. 
BOX 2: Parallel composition of the commandments.

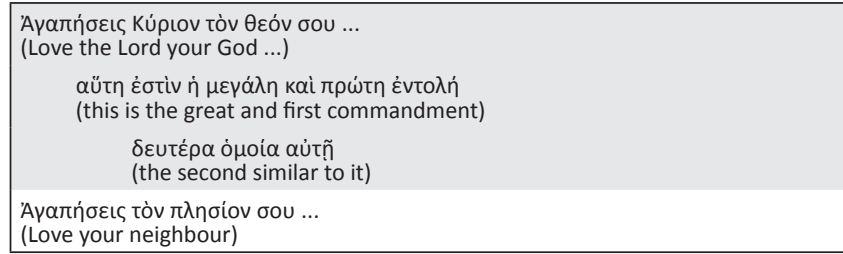

The second commandment can be seen as result of the first, whilst these two commandments are interconnected. Turner (2008:537) remarks: 'Fallen humans cannot love their neighbours as themselves if they have not first acknowledged their obligation to love the only true God' and 'the theocentric vertical obligation is the basis of the anthropocentric horizontal obligation'. Without loving one's neighbour, one cannot love God, since one expresses one's love of God by obeying his commandments and many of these commandments are about human relationships.

Also in this second commandment the meaning of 'love' is determined by the interpretation of Leviticus 19:18 in its contemporary Jewish interpretation (Luz 2001:83). Leviticus 19:11-18 deals with God's ethical commandments about the neighbour, the socially weak and the opponent in a court of Law. Loving is defined as not to steal from, not to lie to, not to deceive, not to swear falsely against, not to defraud or rob one's neighbour, et cetera. Leviticus 19:34 also includes aliens living in their land. Though some Jewish interpreters regarded foreigners as neighbours (Test. of Iss. 7:6), and others included aliens and proselytes (Jub 7:20; 20:2; $36: 4)$, they mostly regarded Israelites only as 'neighbours' (CD 6.20-21; Jos. War. 2.119; Test. of Sim. 4:6-7) as people deserving of Israel's love.

Malina and Neyrey (1996:153-201) provide a helpful perspective to define neighbourly love in the ancient Mediterranean world. They point out that the Mediterranean people lived in collectivist societies that were grouporientated and non-individualistic. The individual person was always a group embedded person connected to a social unit that forms around a notable person. The individual shares the group's loyalty towards the notable person and forms a virtual identity with the group as a whole and with other members in the group. Loyalty and solidarity keep the group together. The love of neighbours entails such group connection. Love is considered as faithfulness and loyalty towards the group in whom one is embedded. The welfare of the group was the concern of each member of the group. Loving one's neighbour implies promoting, protecting and if needed, restoring a person's honour and status within the community (Meier 2009:492).

Reading the Matthean Gospel it seems that Jesus, and for that matter the Matthean community, had a broader view of the group that should be loved than what the Jews commonly thought. From Matthew's text, it seems that the Jews ${ }^{27}$ limited neighbourly love to Israelites or fellow members of the cultic community (Meier 2009:492). In the Matthean tradition, however, the notion of a neighbour ( $\dot{\delta} \Pi \lambda \eta \sigma i ́ \delta)$ is broadened to include people that the Jews usually would regard as outsiders. This is clear from Jesus' command in the sixth antithesis to love one's enemy '... for the Father in heaven causes his sun to rise on the evil and the good, and sends rain on the righteous and the unrighteous' (5:43-48) and the golden rule, 'do to others what you would have them do to you' (7:12). In the light of the Great Commission in 28:18-20 it seems that the Matthean community advocated gentile mission. This must have been controversial in Jewish communities. In a Hellenistic culture within the Roman Empire the Jews struggled to maintain their unique identity. There was a strong tendency towards exclusiveness by drawing strict lines between their communities and outsiders. This must have created much tension between the Jews and the Matthean community who crossed these borderlines because of their mission-mindedness.

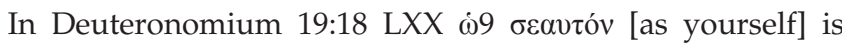
interpreted as direct object: love your neighbour as you love yourself (Luz 2001:83). According to some traditional Jewish understanding loving oneself was commendable (Wis. 19:8). According to the Targum Yerushalmi 1, reference to 'as yourself' does not imply surrendering yourself, but is intended to overcome inequalities and injustices in the community. However, Baba Mesia 62a records the words of Rabi Akiba taking self-love even a step further: 'Your own life takes precedence over the life of your neighbour.'

The research of Malina and Neyrey (1996:153-201) on the embeddedness of each individual into a society adds perspective to the love of oneself. As group-orientated persons, the main concern of the individual was that of his or her group. The welfare of the group assures the welfare of each member of the group. Self-love is therefore incorporated in love for one's group. Meier (2009:492) provides further

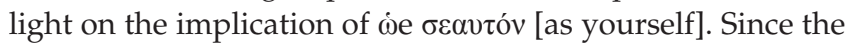
neighbour should be regarded as a fellow-member of the cultic community, he or she should enjoy similar rights, privileges, support and honour than the person who is addressed in the command expects from his or her community.

Reading self-love in Matthew from this perspective, it shows that the teachings of Jesus must have been quite controversial. Jesus broadens the boundaries of love and therefore also the exposure of the self. In the Sermon on the Mount Jesus teaches that one should love one's enemy (5:43-47). Such love crosses the traditional boarders of love. Jesus also commands not to resist an evil person, but to turn the other cheek (5:38-42). There is a good reason for this: it is for the sake of the new community that gathers around Jesus as the leading personage of this group. Matthew describes how Jesus was willing to lay down his life to give it as ransom to many (20:26-28) so that this new community could be established. Jesus expects his followers to be willing to sacrifice themselves if needed to follow him and for the sake of this community (10:37-39; 16:24-26). 


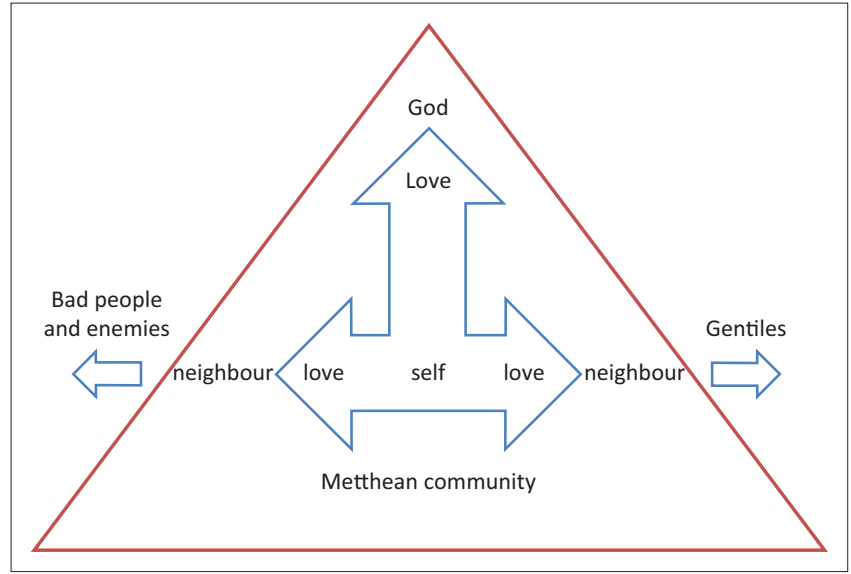

FIGURE 1: Double love commandment.

On the other hand, Jesus teaches 'do to others what you would have them to do to you' (7:12). Though Matthew's Jesus does not propagate an unconditional self-denial, he proposes a willingness to do so for the sake of the broadening of the community of his followers in whom the individual is embedded. Whilst Matthew's Jesus accuses the teachers of the Law and Pharisees of being hypocrites in their attempt to win a single convert (23:15), he defines neighbourly love in such a way that it enhances his missional drive (cf. 28:19).

The following figure (Figure 1) illustrates the double love commandment within Matthew's Gospel. The 'self' expresses his or her love to God in a vertical dimension and to the neighbour on a horizontal dimension. The commandment to horizontal love, however, crosses the boundaries of the community to reach even the enemies, people considered to be bad, and the gentiles.

\section{All the Law and the Prophets hang on the double love commandment}

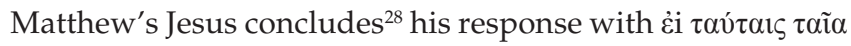

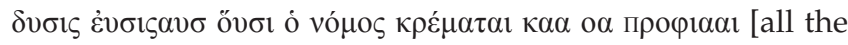
Law and the Prophets hang on these two commandments] (22:40). This reference to the Law and the Prophets closely links this double love commandment to two other passages in which this reference is also made, namely Jesus' foundational statement on the Law $(5: 17)^{29}$ and his admonishment that one should do to others what one wants others to do to oneself $(7: 12)^{30}$ in the Sermon on the Mount. Jesus confirms that these two commandments are nothing new when compared to Israel's Bible. As a matter of fact, they are its fulfilment.

The direct combination of Deuteronomium 6:5 and Leviticus 19:18 does not appear in Jewish writings, though it is suggested in some of them (Gerhardsson 19976:146; Luz

28.As indicated before, verse 40 could probably also be a comment made by Matthew on the great commandments.

29.Matthew 5:15 reads: 'Do not think that I have come to abolish the Law or the Prophets; I have not come to abolish them but to fulfil them.'

30.Matthew 7:12 reads: 'So in everything, do to others what you would have them do to you, for this sums up the Law and the Prophets.'
2001:84). In the Letter to Aristeas 131, Philo places the two tablets of the Decalogue respectively under two headings: the first being $\varepsilon$ the $\beta \varepsilon 1 \alpha$ [piety] and oand fi [devoutness],

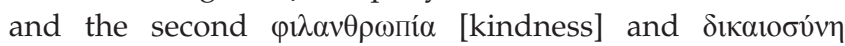

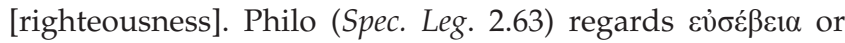

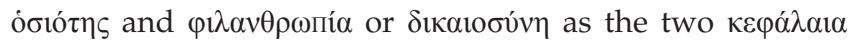
[headings] of the divine $\delta$ ó $\gamma \mu \alpha \tau \alpha$ [teachings]. The Sipre Deuteronomium 32.29 regards the fear of God and the works of love as the centre of the Torah.

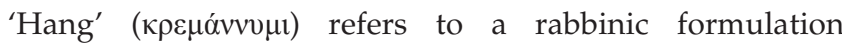
(Donaldson 1995:689-709). This expression has the meaning of something depending on an overarching principle, like a door hanging on its hinges ${ }^{31}$ (Luz 2001:85). Lohmeyer (1962:329) fittingly calls the double love commandment the 'double peg' on which the entire Torah and Prophets depend. Osborne (2010:824) argues that this is fulfilment language, similar to Paul's words in Romans 13:10: 'Therefore love is the fulfilment of the law'. All Scripture is an exposition of the ideals expressed in Deuteronomium 6:5 and Leviticus 19:18 (Turner 2008:536). All the commandments of the Torah and Prophets are somehow related to the commandment to love God and to love one's neighbour. Whilst keeping this big commandment, one also has to keep the small commandments (cf. 5:17-19; 23:23). These two commandments form the basis for all relationships and ethics. Hagner (1995:647) fittingly remarks: 'This is a way of saying that the commandments of the law and the teaching of the prophets cannot be fulfilled apart from the twofold love commandment' and Barth (1963:77) writes: 'The whole law and the prophets can be exegetically deduced from the command to love God and the neighbour, they 'hang' exegetically on these.' This statement probably reflects the reaction of the Matthean community against what they experienced as the casuistry of the Pharisees (cf. 23:23ff.; Hultgren 1974:377).

These two commandments form the 'hermeneutic program' for the understanding and application of the Torah and Prophets in the Matthean Gospel (Gerhardsson 1976:129-150). According to Matthew, the interpretation and application Bible books of Israel should be guided by the two commandments of love. It forms the 'canon of interpretation' (Bornkamm 1954:93), which should steer all the exegesis of Torah and the Prophets. This is probably also the guiding principle Matthew proposes and expects from his community when interpreting those documents.

The similarity between Jesus' teaching on the Torah in 22:34-40 and the Sermon on the Mount (5-7) is significant. Both of these teachings describe the close connection between the love of God and the love of one's neighbour. Furthermore, both these passages refer to the 'Law and the Prophets'. The phrase, the Law and the Prophets, forms an inclusion of 5:17-7:12 and of 22:34-40.

31.B. Ber. 63a uses the same expression, stating that Proverbs 3:6 forms the text on
which all Torah principles depend and Ex. Rab. on Exodus $21: 1$ states that the which all Torah principles depend
whole Torah 'hangs' on justice. 


\section{Conclusion}

The double love commandment can be regarded as foundational to Matthew's Jesus' teaching on the Torah, as Matthew's Jesus (or the author) states that all the Law and the Prophets hang on these two commandments. This statement probably parallels the Shema (Dt 6:4-9) in importance in the Gospel. McKnight (2004:viii) calls it 'the Jesus creed', and the vision of Jesus. McKnight (2004:viii) summarises this vision of Jesus as: 'A spiritually formed person loves God by following Jesus and loves others.' Whilst the expert of the Law challenges Jesus to distinguish between or rank the commandments, Jesus explains in his riposte the coherence and centre of God's will. The double love commandment epitomises the Torah and forms the overarching principle to which all the commandments are connected and should be interpreted. It can be assumed that the double love commandment also stands central to Matthean ethics. As group-oriented people, the ancient Mediterranean people saw love towards God as implying faithfulness and loyalty towards his people. Piety towards God manifests in faithfulness and loyalty towards the group in which one is embedded. In this embedded group, love has both a vertical dimension, focusing on God as the basic personage in whom all are embedded, and a horizontal dimension, focusing on fellow members of the embedded community. These two dimensions are closely related. One cannot love God without loving one's neighbour or the other way around. One's love of God motivates one's love for neighbours. Loving community-directed ethical behaviour is rooted in a loving relationship with God. Love of God or love of one's neighbour cannot be absorbed in one another. Though they are inseparable, they are different. Loving God is not the same as loving one's neighbour and love is more than human ethics.

Interpreting the double love commandments in both the original as Matthean contexts, it becomes clear that love does not imply a mere feeling or mystical flight into union with God. It implies knowledge and obedience of God and his commandments. In its vertical dimension love implies reverence, obedience and commitment to God. In its horizontal dimension love implies unselfish acting towards others with their well-being as goal.

The double commandment on love is no new principle given by Jesus. Both these commandments find their roots in the Bible of Israel. Though the direct combination of these two commandments does not appear in Jewish interpretation, Jewish writers did associate them with one another and with the two tablets of the Decalogue respectively.

In Matthew Jesus' teaching about loving one's neighbour differs from traditional Jewish teachings. Whilst the Jews predominantly limited neighbourly love to fellow Jews, proselytes or aliens within their borders, Jesus taught love beyond such borders. Jesus instructed his disciples to go out and make disciples of all nations (28:19). People of all nations were to be baptised in the name of the Father and the Son and the Holy Spirit. Thus, they would be embedded into the community in which the Father, Son and Holy Spirit form the basic personages. Love even had to be extended towards enemies (5:43). Loving enemies has implications for self-loving. Jesus takes self-love for granted as model for the way one should love one's neighbour, but extends neighbourhood to include people who the Jews regarded as outsiders. The specific connotation that self-love had in a group-orientated society, implied that one had to be willing to sacrifice oneself for the benefit of the group as Jesus did (20:28). One should be willing to turn the other cheek for the sake of the Kingdom of God (5:39). In a group-orientated community, one unselfishly had to seek the good of other members for the sake of the group.

Jesus' answer to the expert of the Law about the greatest commandment is closely related to his teaching about the Law in the Sermon on the Mount. In both cases Jesus confirms that he upholds the Law and the Prophets and that he ensures their fulfilment. Jesus has no intention of abolishing the Law.

It is clear that the double love commandment stands central to Matthean ethics. It seems as if the Matthean Pharisees had a casuistic approach to the Law and the Prophets, whilst the Matthean community viewed the double love commandment as the basis for understanding the Law and the Prophets and from which particularities proceed.

With this short narrative, Matthew obviously wants to define the lifestyle of his community. They were not to retreat from this world. Love of God should be demonstrated in faithful obedience to God's will and active compassion with people. The Gospel concludes with the assurance that Jesus had received all authority and thus became an important personage in the community. People of the Matthean community were expected to obey everything Jesus has commanded them (28:20), which includes his teaching on love.

\section{Acknowledgements Competing interests}

The author declares that he has no financial or personal relationship(s) that may have inappropriately influenced him in writing this article.

\section{References}

Barth, G., 1963, 'Matthew's understanding of the Law' in G. Bornkamm, G. Barth \& H.J. Held (eds.), Tradition and interpretation in Matthew, pp. 58-164, Westminster Press, Philadelphia.

Baumgartel, F., 1978, 'Ka $\alpha \delta$ ía', in G. Kittel (ed.), Theological Dictionary of the New Testament, vol. 3, pp. 605-607, William Eerdmans Publishing Company, Grand Testament,
Rapids.

Behm, J., 1978, 'Heart', in G. Kittel (ed.), Theological Dictionary of the New Testament, vol. 3, pp. 605-607, William Eerdmans Publishing Company, Grand Rapids.

Berger, K., 1972, Die Gesetzesauslegung Jesu: Ihr im Judentum und im Alten Testament, Neukirchener Verlag, Neukirchen-Vluyn.

Bornkamm, G., 1954, 'Das Doppelgebot der Liebe', in R. Bultmann (ed.), Neutestamentliche Studien, pp. 85-93. Beihefte zur Zeitschrift für die neutestamentliche Wissenschaft, Alfred Töpelmann, Berlin.

Carrigan, H.L., 2000, 'Soul', in D.N. Freedman, A.C. Myers \& A.B. Beck (eds.), Eerdmans Dictionary of the Bible, p. 1245, William Eerdmans Publishing Company, Grand Rapids \& Cambridge. 
Carter, W. 2000, Matthew and the margins. A Socio-Political and Religious reading, Sheffield Academic Press, Sheffield. (Journal for the Study of the New Testament Supplement Series, 204).
Sulfield Academic Press,

Davies, W.D. \& Allison D.C., 2004, A Critical and exegetical commentary on the Gospel according to Saint Matthew, vol. 3 (Mt 19-28), T\&T Clark International, London \& New York. (International Critical Commentary).

Dihle, A., 1974, ' $\Psi v \chi \eta$ in the Greek world', in G. Friedrich (ed.), Theological Dictionary of the New Testament, vol. 9, pp. 608-617, William Eerdmans Publishing Company, Grand Rapids.

Donaldson, T.L., 1995, 'The Law that hangs (Mt 22:40): Rabbinic formulation and Matthean social world, Catholic Biblical Quarterly 57, 689-709.

Gerhardsson, B., 1976, 'The hermeneutic program in Matthew 22:37-40', in R. Hammerton-Kelly \& R. Scroggs (eds.), Jews, Greeks and Christians. Religious cultures in late antiquity, pp. 129-150, Brill, Leiden.

Hagner, D.A., 1995, Matthew 14-28, Word Books, Dallas. (Word Biblical Commentary 33B).

Hultgren, A.J., 1974, 'The double commandment of love in Matt. 22:34-40; its and sources and compositions', Catholic Biblical Quarterly 36, 373-378.

Jacob, E., 1974, 'The anthropology of the Old Testament', in G. Friedrich (ed.), Theological Dictionary of the New Testament, vol. 9, pp. 617-631, William Eerdmans Publishing Company, Grand Rapids.

Keener, C.S., 2009, The Gospel of Matthew. A Socio-Rhetorical Commentary, Eerdmans, Grand Rapids/Cambridge.

Loader, W.R.G., 1997, Jesus' attitude towards the law: A study of the Gospels, Siebeck, Tübingen. (Wissenschaftliche Untersuchungen zum Neuen Testament).

Lohmeyer, E., 1962, Das Evangelium des Matthäus, Vandenhoeck \& Ruprecht, Göttingen.

Luz, U., 2001, Matthew 21-28, Fortress Press, Minneapolis.

Malina, B.J. \& Neyrey, J.H., 1996, 'Portraits of Paul. An Archaeology of ancient personality', Westminster John Knox Press, Louisville.

Malina, B.J. \& Rohrbaugh, R.L., 1992, Social-science commentary on the Synoptic Gospels, Fortress Press, Minneapolis.

McKnight, S., 2004, The Jesus Creed: Loving God, loving others, Paraclete, Brewster.
Meier, J.P., 2009, A marginal Jew; rethinking the historical Jesus: Love and Law, vol. 4 Yale University Press, New Haven \& London.

Montifiore, C.C. \& Loewe, H.M.J., 1974, A rabbinic anthology, Cambridge University Press, Cambridge.

Osborne, G.R., 2010, Matthew, Zondervan, Grand Rapids. (Zondervan exegetical commentary on the New Testament).

Piper, J., 1979, Love your enemies; Jesus' love command in the Synoptic Gospels and the early Christian paraenesis, University Press, Cambridge.

Repschinski, B., 2000, The controversy stories in the Gospel of Matthew: Their redaction, form and relevance for the relationship between the Matthean community and formative Judaism, Vandenhoeck \& Ruprecht, Göttingen community and formative Judaism, Vanden

Sanders, E.P., 1985, Jesus and Judaism, Fortress Press, Philadelphia

Schweizer, E., 1974, ' $\Psi v \chi \eta$ in the New Testament', in G. Friedrich (ed.), Theological Dictionary of the New Testament, vol. 9, pp. 637-656, William Eerdman Publishing Company, Grand Rapids.

Spencer, R.A., 2000, 'Mind', in D.N. Freedman, A.C. Myers \& A.B. Beck (eds.), Eerdmans Dictionary of the Bible, p. 901, William Eerdmans Publishing Company, Grand Rapids \& Cambridge.

Stanton, G.N., 1992, A Gospel for a New People: Studies in Matthew, T\&T Clark, Edinburgh.

Stanton, G.N., 2013, Studies in Matthew and early Christianity, Mohr Siebeck, Tübingen. (WUNT 309).

Stein, R.H., 2008, Mark, Baker Academic, Grand Rapids. (Baker exegetical commentary on the New Testament).

Turner, D.L., 2008, Matthew, Baker Academic, Grand Rapids. (Baker exegetical commentary on the New Testament).

Walker, L.L., 2000, 'Heart', in D.N. Freedman, A.C. Myers \& A.B. Beck (eds.), Eerdmans Dictionary of the Bible, p. 563, William Eerdmans Publishing Company, Grand Rapids \& Cambridge.

Würthwein, E., 1978, 'Alavoía', in G. Kittel (ed.), Theological Dictionary of the New Testament, vol. 4, pp. 963-968, William Eerdmans Publishing Company, Grand Rapids. 